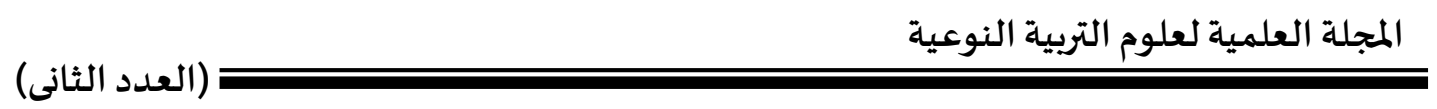

\title{
BIOLOGICAL STUDIES ON SOME NUTRITIONAL PRODUCTS SUPPLEMENTED WITH FISH OIL FOR HYPERLEPIDMIC RATS
}

\author{
Hamdia Ahmed Helal, Nehad R.EL-Tahan, Mai Abd Elkahlik Gharib and \\ Eman saied Abo El Magd.
}

Nutrition and Food Science Dep., Home Economic faculty, Monifiya University.

\begin{abstract}
:
Reducing intake of saturated fat, dietary cholesterol and avoiding excess calories, which can lead to obesity, remain the cornerstone of the dietary approach to decreasing risk of atherosclerotic vascular disease. During the past 20 years, there has been renewed interest in other dietary components that might favorably improve lipid profiles and reduce risk of coronary heart disease (CHD). Fish oil, rich sources of omega-3 fatty acids, have sparked intense interest in both epidemiological studies, which suggest a favorable effect on CHD, and metabolic ward studies, which show a striking improvement in lipid profiles in hyperlipidemic patients. This research aimed to study the biological properties of some nutritional products supplemented with fish oil on hyperlipidemic rats. Thirty female albino rats ( 30 female), weighing $140 \pm 5$ g were divided into 6 groups and administered fish oil products daily for 28 days. Blood samples were taken from each rat and tested for total cholesterol, (LDL), (HDL), triglycerides, liver enzymes activities, kidney functions, progesterone and PRL hormone. Results showed that triglycerides, total cholesterol, LDL, VLDL, and liver enzymes activities (AST and ALT) were significantly increased, while HDL was significantly decreased in positive control group compared with the negative control rats. Treating hypercholesterolemic rats with 20\%pizza contained $10 \%$ and $15 \%$ fish oil in hypercholesterolemic diet caused a significant improvement in these biochemical measures and the best results were achieved by using basal diet with $20 \%$ pizza contained $(15 \%)$ fish oil. So, it could be concluded that fish oil is useful for hyperlipidemic patients and for the prevention of heart disease and hardening of the arteries.
\end{abstract}

Key words: hypercholesterolemic rats; fish oil; lipid profile; kidney functions. 
دراسات تكنولوجية وبيولوجية علي المنتجات الغذائية المدعمة بزيت السمك للفئران

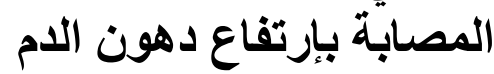

د/ إيمان سعيد أبوالمجد

المستخلص العربي

أجريت الدر اسة بهذف دراسة الخو اص التكنولوجية و البيولوجية لبعض المنتجات الغذائية المدعمة

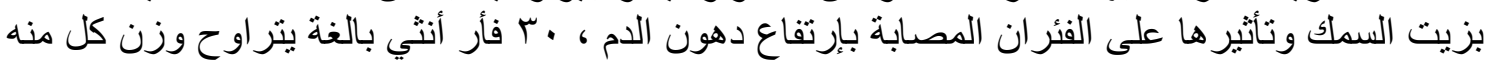

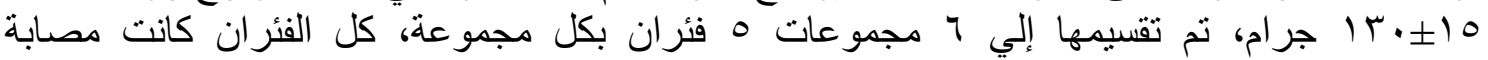

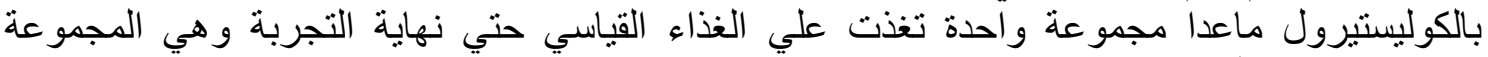

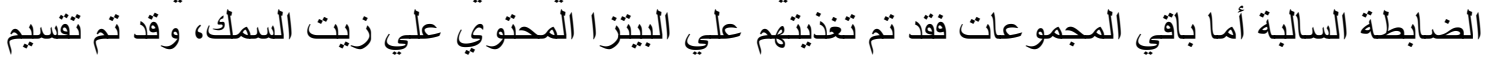

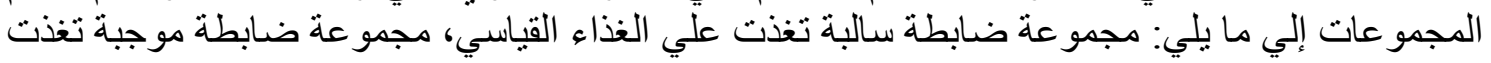

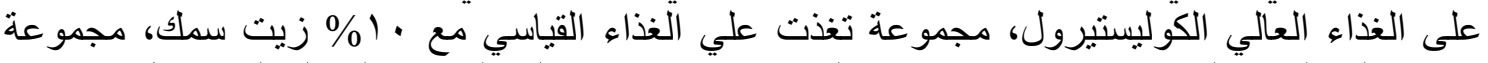

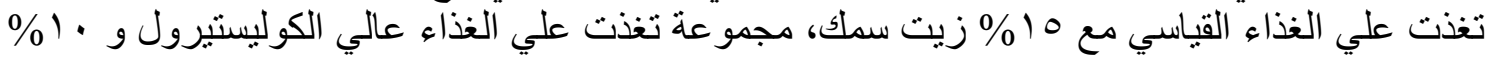

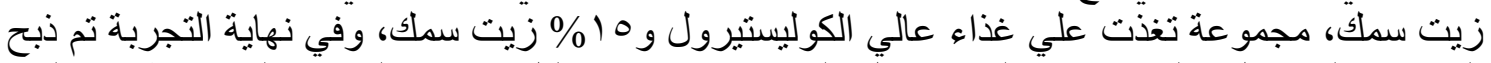

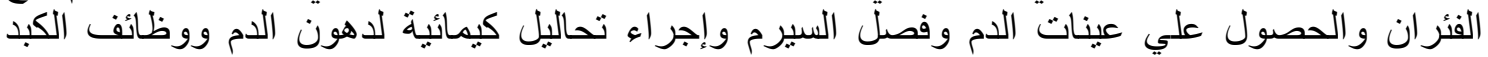
ووظائف الكلي.

وحدث انخفاض بدرجة معنوية عالية بالنسبة لنسبة الكوليستيرول والجليسريدات الثنلاثية

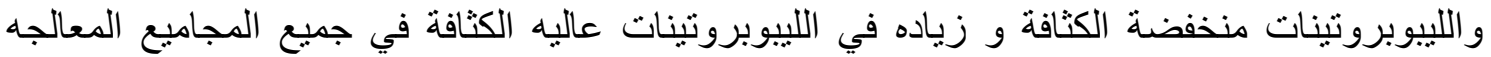

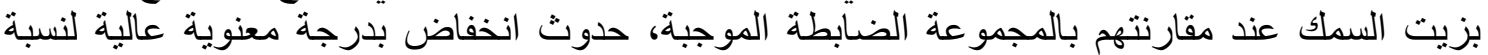

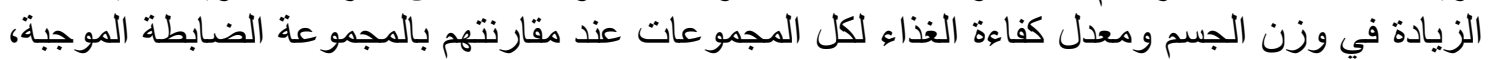

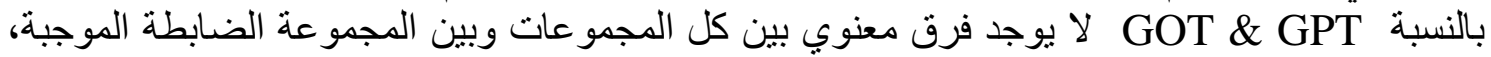
بالنسبة لحمض اليوريك لا فرق معنوي بين كل المجمو عات وبين المبن المجمو عة الضابطة الموجبة.

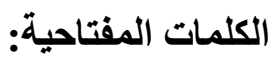

الكوليستيرول - زيت السمك - فئر ان - تقييم بيولوجي. 
(العدد الثانى)

\section{Introduction:}

Hyperlipidemia characterized by hypercholesterolemia is the most prevalent indicator for susceptibility to cardiovascular diseases. World health organization reports that high blood cholesterol contributes to approximately $56 \%$ of cases of cardiovascular diseases worldwide and causes about 4.4 million deaths each year (Dhuley et al.,1999) .

Since cholesterol is insoluble in water, it is transported in the blood plasma within protein particles (lipoproteins). Lipoproteins are classified by their density very low density lipoprotein (VLDL), intermediate density lipoprotein (IDL), low density lipoprotein (LDL), and high density lipoprotein (HDL) (Biggerstaff \& Wooten, 2004). All the lipoproteins carry cholesterol, but elevated levels of the lipoproteins other then HDL (termed non-HDL cholesterol), particularly LDL-cholesterol are associated with an increased risk of atherosclerosis and coronary heart disease (Carmena et al., 2004). In contrast higher levels of HDL cholesterol are protective (Kontush \& Chapman, 2006). Elevated levels of non-HDL cholesterol and LDL in the blood may be a consequence of diet, obesity, inherited (genetic) diseases (such as LDL receptor mutations in familial hypercholesterolemia), or the presence of other diseases such as diabetes and an underactive thyroid (Durrington, 2003).

Dietary fish oils have been the subject of many investigations in recent years due to their effects on the cardiovascular system (Leaf and Weler, 1988).

Fish oils have been demonstrated to have dramatic effects on hepatic and plasma lipid and lipoprotein metabolism, particularly on the metabolism triacylglycerols (TAG) and triacylglycerol- rich lipoproteins (Herzberg, 1991).

Liu et al. (2001) investigated the effects of daily intake of a small amount of fish oil in bread. They found that in subjects with hyperlipidemia intake of bread containing a small amount of fish oil results in a significant increase in omega-3 fatty acids, an increase in HDL-cholesterol, and a decrease in triglycerides and MDA, which may reduce the risk of ischemic heart disease.

\section{MATERIALS AND METHODS:}

\section{Materials:}

Cholesterol, fish oil (cod liver oil), casein, starch, vitamin mixture and salt mixture were obtained from El-Gornhoriya, Company for Chemical and Medical Equipments, Cairo, Egypt.

\section{Animals}

Male albino rats $(140 \pm 5 \mathrm{~g})$ of Sprague Dawley strain were obtained from the Laboratory of Animal Colony, Ministry of Health and Population, Helwan, Cairo, Egypt. The rats were kept under controlled conditions in plastic cages. 


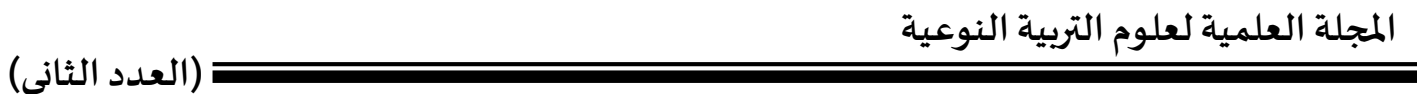

\section{Diets}

The basal diet consists of casein (12\%), com oil (10\%), methionin $(0.3 \%)$ choline chloride $(0.2 \%)$, vitamin mixture $(1 \%)$ according to Campbell (1963), cellulose (5\%), salt mixture (4\%) according to Hegsted et al. (1941) and corn starch (up to $100 \%$ ),

\section{Preparation of Pizza:}

Pizza is prepared according to Awad (1998) using the flour and different levels of cod liver at the levels $(5,10$ and $15 \%)$ by replacing the corn oil

The dough recipe of control sample $(217 \mathrm{~g})$ was as follow:

$100 \mathrm{~g}$ white wheat flour

$25 \mathrm{~g} \quad$ corn oil

$\begin{array}{cc}50 \mathrm{~g} & \text { milk } \\ 5 \mathrm{~g} & \text { yeast } \\ 2 \mathrm{~g} & \text { salt } \\ 25 \mathrm{~g} & \text { egg } \\ 2 \mathrm{~g} & \text { sugar } \\ 3 \mathrm{~g} & \text { green pepper } \\ 5 \mathrm{~g} & \text { tomato }\end{array}$

After white flour and mixed oil, milk and egg are added with yeast and sugar, finally little salt and water were in corporate to holding dough. The dough is weight and formed by spreading and cutting into round pieces, slices of tomato and green pepper formed the cover of surface. Fish oil was added to pizza dough by the replacement of corn oil at the levels 10 and $15 \%$.

\section{Induction of Hyperlipidemia:}

High cholesterol diet was prepared by mixing cholesterol $2 \%$, coconut oil $2 \%$ or $30 \%$, with standard powdered standard animal food. The diet was placed in the cage carefully and was administered for seven days [Pandya et al., 2006].

\section{Experimental design}

The experiment was conducted in the Agricultural Research Center, Animal Production Research Institute, Giza - Egypt. Rats were housed in wire cages in a room maintained at $25 \pm 2{ }^{\circ} \mathrm{C}$ and kept under normal healthy conditions. All rats were fed on basal diet for one week before starting the experiment for acclimatization. After one-week period, the rats were fed on the hypercholestermic diet except the first group fed on basal diet (control negative) and rats divided into 6 groups as follow:

Group1: Rats was fed on basal diet as negative control (healthy rats).

Group2: Rats was fed on hypercholesterolemic diet as positive control (hyperchloesterolemic rats)

Group3: Hypercholesterolemic rats was fed on basal diet and 20\% pizza supplemented with (10\%) cod liver oil.

Group4: Hypercholesterolemic rats was fed on basal diet with20\% pizza supplemented with (15\%) cod liver oil.

Group5: Hypercholesterolemic rats was fed on Hypercholesterolemic diet and $20 \%$ pizza supplemented with (10\%) cod liver oil. 


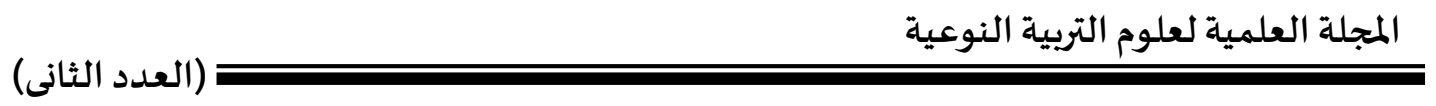

Group6: Hypercholesterolemic rats was fed on Hypercholesterolemic diet with pizza supplemented with $(15 \%)$ cod liver oil.

\section{Collection of blood:}

On the 28 day, blood was collected by retero orbital sinus puncture, under mild ether anesthesia after $8 \mathrm{hr}$ fasting and allowed to clot for 30 minutes at room temperature. Blood samples were centrifuged at $3000 \mathrm{rpm}$ for 20 minutes. Serum was separated and stored at $-20 \square \mathrm{C}$ until biochemical estimations were carried out.

\section{Biological evaluation:}

At the end of the experiment, biological evaluation of the different diets carried out by determination of daily feed intake (consumption), relative organs weights (\% of body weight), body weight gain\% (BWG \%) and feed efficiency ratio (FER) according to Chapman et al. (1959) using the following formulas.

$\mathrm{BWG}=\underline{\text { Final weight }- \text { initial weight } \mathrm{xl} 0 \mathrm{O}}$

Initial weight

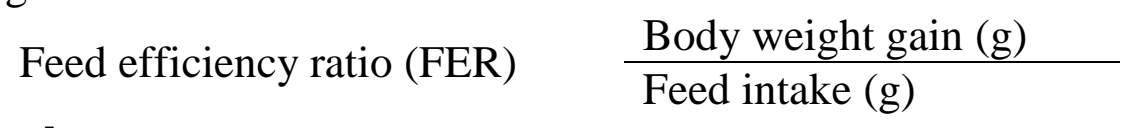

\section{Biochemical assay:}

The following determinations were carried out on serum samples : Serum cholesterol was determined according to (Wotton, 1964).Enzymatic determination of triglycerides in scrum was conducted according to(Van Handel and Zilversmit, 1957). HDL-Cholesterol was determined after separation of high density lipoprotein and determination of cholesterol bound to this fraction(Farish and Fletcher, 1983). LDL-Cholesterol was determined according to the method of Farish and Fletcher, (1983). Albumin was determined according to the method described by Doumas and Biggs, (1971). Uric acid was estimated according to the method described by Barham and Trinder (1972). Creatinine was determined according to the method described by Schimeister, (1971).Colorimetric determination of the activity of GPT (ALT) and GOT (AST) activity were according to method described by Reitman and Frankel (1957). Urea was determined according to the method described by Fawcett and Scott, (1960). Prolactine and progesterone level were determined according to Hirai ( 1982).

\section{Statistical analysis}

Statistical analysis were done using the Statistical Package for the Social Sciences (SPSS for WINDOWS, version 11.0; SPSS Inc, Chicago). Comparative analyses were conducted by using the general linear models procedure (SPSS Inc). Values of $\mathrm{P}<0.05$ were considered statistically significant.

\section{Results and discussion:}

\section{Biological Evaluation:}

Data in table (1) indicated that the mean value of feed intake in the negative control group was $14.321 \mathrm{~g} / \mathrm{day}$, while the mean value of positive control group that is fed on basal diet containing $2 \%$ cholesterol was $12.213 \mathrm{~g} /$ day. The mean values of feed intake of hypercholesterolemic group fed on basal diet and treated 
with pizza with fish oil at level 10 and $15 \%$ were 12.67 and 13.14 g/day respectively. while feed intake of hypercholesterolemic groups fed on hypercholesterolemic diet and treated pizza with fish oil at the level 10 and 15\% were 12.642 and $12.53 \mathrm{~g} /$ day respectively. From this table, It could be noted that the differences in values of feed intake between all treated groups were significant, as compared to control groups and group fed on pizza with 15\% fish oil. For FER, hypercholesterolemic groups that fed on basal diet containing 10\% and $15 \%$ fish oil in pizza as treatment showed decreasing in FER values compared to the groups fed on hypercholesterolemic diet containing $10 \%$ and $15 \%$ fish oil in pizza as prevention. There is no significant differences between all groups. After the induction of high cholesterol in rats, and feeding pizza with fish oil with two different concentration (10 and 15\%) for the prevention and treatment.

BWG of the group fed on hypercholesterolemic diet (control +) showed significant increase as compared to negative group (control -). Feeding rats on basal diet contining 10 and $15 \%$ fish oil in pizza showed non-significant changes, while the groups fed on hypercholesterolemic diet containing 10 and $15 \%$ fish oil in pizza induced significant increase in BWG as compared to control group (control +) and (control -).The observed effect of fish oil on feed intake and body weight (Table 1) in this study was agreed with that reported by (Ruzickova, et al., 2004) who found that the fish oil; like any fat, is rich in calories. However, most people eat to satiety. Patients taking fish oil at the rate of $15 \mathrm{ml} / \mathrm{day}$ immediately before or during a meal did not increase their mean weight over 1 year; there is no significant mean change of $-0.4 \mathrm{~kg}$ from baseline to 1 year. So, metabolic studies suggested fish oil can reduce adipocyte numbers and the contribution of adipose tissue to body mass

Table (1): Effect of pizza supplemented with different levels of fish oil on Feed intake (FI), Feed efficiency ratio (FER) and Body weight gain (BWG):

\begin{tabular}{|l|l||l||l||}
\hline Groups & FI & FER & BWG \\
\hline \hline Control negative & $14.321 \pm 1.05^{\mathrm{a}}$ & $0.191 \pm 0.011^{\mathrm{a}}$ & $42.27 \pm 1.2^{\mathrm{b}}$ \\
\hline \hline Control positive & $12.213 \pm 0.91^{\mathrm{b}}$ & $0.101 \pm 0.01^{\mathrm{a}}$ & $47.86 \pm 1.34^{\mathrm{a}}$ \\
\hline \hline Fish oil feed level 10\% & $12.67 \pm 1.02^{\mathrm{b}}$ & $0.091 \pm 0.07^{\mathrm{a}}$ & $41.91 \pm 2.02^{\mathrm{b}}$ \\
\hline \hline Fish oil feed level 15\% & $13.14 \pm 1.11^{\mathrm{a}}$ & $0.089 \pm 0.08^{\mathrm{a}}$ & $41.1 \pm 3.14^{\mathrm{b}}$ \\
\hline $\begin{array}{l}\text { Fish oil feed level 10\% } \\
\text { with cholesterol }\end{array}$ & $12.642 \pm 2.11^{\mathrm{b}}$ & $0.191 \pm 0.12^{\mathrm{a}}$ & $138 \pm 1.31^{\mathrm{c}}$ \\
\hline $\begin{array}{l}\text { Fish oil feed level 15\% } \\
\text { with cholesterol }\end{array}$ & $12.53 \pm 0.09^{\mathrm{b}}$ & $0.178 \pm 0.01^{\mathrm{a}}$ & $108.9 \pm 6.31^{\mathrm{d}}$ \\
\hline \hline
\end{tabular}

Each value represent the mean of 5 rats \pm SD. Values significantly different compared to normal: $P \leq 0.05$. Same letter means non-significant. 


\section{2- Biochemical Analysis}

\section{2-1- Effect of pizza supplemented with different levels of fish oil on lipid} profile of hypercholesterolemic rats.

Data in table (2) showed that, total cholesterol and triglycerides levels $(\mathrm{mg} / \mathrm{dl})$ increased significant $(\mathrm{P} \leq 0.05)$ for rats fed on hypercholesterolemic diet (control positive), compared to healthy rats fed on basal diet (control negative). Total cholesterol and triglycerides decreased significantly $(\mathrm{P}<0.05)$ when hypercholesterolemic rats fed on basal diet contained 10 and $15 \%$ fish oil in pizza compared to hypercholesterolemic rats fed on hypercholesterolemic diet containing 10 and $15 \%$ fish oil in pizza (as prevention). The statistical analysis showed a significant decrease in total cholesterol and triglycerides of all treated groups when compared with control positive. Treatments under study reduced serum cholesterol and triglycerides concentration. However, the highest reduction was achieved by feeding basal diet containing 15\% fish oil in pizza.

In accordance with the present results, Hirako et al. (2011) demonstrated that low-dose fish oil diets improve lipid metabolism by modifying the expression of lipid metabolism-related genes in the liver and increasing fecal cholesterol excretion, while Carrepeiro et al., (2011) Combining statins and n-3 fatty acids is an excellent strategy to reduce plasma cholesterol and triacylglycerol concentration in women. However, n-3 fatty acids increased the oxidative stress and the pleiotropic effect of statins seemed to be not enough to counterbalance this result. Our data also suggested that the mechanism by which n-3 fatty acids interfere in oxidative stress can be associated with antioxidant enzymes expression and activity. The mean values of serum HDL-C of all treated rats with fish oil were increased significantly $(\mathrm{P} \leq 0.05)$, as compared to control $(+)$. Concerning levels of fish oil, the highest mean value of HDL-C was obtained when rats were fed on hypercholesterolemic diet containing $15 \%$ fish oil in pizza, while the lowest mean values of the same parameter was obtained when rats were fed on basal diet containing $15 \%$ fish oil in pizza. From the obtained data, it could be concluded that HDL-C affected with the presence of levels of fish oil. The highest decreasing was found in hypercholesterolemic rats fed on $15 \%$ fish oil in pizza.

Data indicated that, feeding rats with hypercholesterolemic diet led to significant increase $(\mathrm{P} \leq 0.05)$ in $\mathrm{LDL}-\mathrm{C}$, compared with control negative group that fed on basal diet. Low density lipoprotein-cholesterol (LDL-C) of hypercholesterolemic rats fed on basal diet and hypercholesterolemic diet containing fish oil decreased significantly $(\mathrm{P} \leq 0.05)$, compared with (control + ). The mean values of the ratio between LDL-C/HDL-C of all rats with levels fish oil were decreased significantly $\mathrm{P} \leq 0.05$, as compared to positive control. Rats fed on basal diet containing $15 \%$ fish oil in pizza led to significant decrease of the ratio between LDL-C/HDL-C, compared with the groups fed on hypercholesterolemic diet containing 10 and $15 \%$ fish oil in pizza. 
The best mean values of the ratio between LDL-C/HDL-C for tested groups were observed in the group fed on basal diet containing $15 \%$ fish oil in pizza.

From the above mentioned data it could be concluded that, total cholesterol, triglycerides, HDL-C, LDL-C and the ratio between LDL-C/HDL-C were more decreased in hypercholesterolemic rats which fed on basal diet with levels of fish oil, and the results of these groups decreased more than the obtained from groups fed on hypercholesterolemic diet containing 10 and $15 \%$ fish oil. These results were in the same line of Lee et al.(2012) which suggested that a dietary intervention focused on n-6 and n-3 fatty acids may improve cardiovascular risk factors in patients over and above standard lipid management. Also, Omega-3 polyunsaturated fatty acids (-3 PUFAs) from marine origin have been strongly associated with cardiovascular protection, even at low doses ( $<\mathrm{lg} / \mathrm{d})$ ( Burillo et al.,2012). Chen et al. (2012) concluded that docosapentaenoic acid (DPA n-3), omega- 6 docosapentaenoic acid (DPA n-6) and docosahexaenoic acid (DHA), were beneficial in improving lipoprotein profile with DPA n-3 and DHA having better effect on aortic

Table (2):Effect of pizza supplemented with different levels of fish oil on lipid profile of hypercholesterolemic rats.

\begin{tabular}{|c|c|c|c|c|c|}
\hline Groups & \begin{tabular}{|l|} 
Total \\
cholesterol
\end{tabular} & Triglyceride & $\begin{array}{l}\text { HDL- } \\
\text { C }\end{array}$ & \begin{tabular}{|l} 
LDL- \\
C \\
\end{tabular} & $\begin{array}{l}\text { LDL- } \\
\text { C/HDL-c }\end{array}$ \\
\hline Control negative & $\begin{array}{l}89.78 \pm 3.2 \\
\text { e }\end{array}$ & $39.4 \pm 0.9^{f}$ & $\begin{array}{l}60.58 \\
\pm 1.2^{\mathrm{a}} \\
\end{array}$ & $\begin{array}{l}20.86 \\
\pm 0.2^{f} \\
\end{array}$ & $0.34 \pm 0.01^{f}$ \\
\hline Control positive & $\begin{array}{l}206.3 \\
1.34^{\mathrm{a}} \\
\end{array}$ & $120.7 \pm 3.4^{\mathrm{a}}$ & $\begin{array}{l}28.38 \\
\pm 3.4^{\mathrm{e}} \\
\end{array}$ & $\begin{array}{l}74.1 \pm \\
2.3^{\mathrm{a}}\end{array}$ & $2.61 \pm 0.13^{\mathrm{a}}$ \\
\hline $\begin{array}{l}\text { Fish oil feed level } \\
10 \%\end{array}$ & $\begin{array}{l}115.3 \\
4.71^{d} \\
\end{array}$ & $74.3 \pm 1.34^{\mathrm{d}}$ & $\begin{array}{ll}40.3 & \pm \\
1.2^{\mathrm{c}} & \\
\end{array}$ & $\begin{array}{l}60.3 \pm \\
3.5^{c}\end{array}$ & $1.5 \pm 0.43^{c}$ \\
\hline $\begin{array}{l}\text { Fish oil feed level } \\
15 \%\end{array}$ & \begin{tabular}{ll|}
133.04 & \pm \\
$5.3^{\mathrm{c}}$ & \\
\end{tabular} & $52.3 \pm 3.4^{\mathrm{e}}$ & $\begin{array}{l}45.97 \\
\pm 1.7^{\mathrm{b}} \\
\end{array}$ & $\begin{array}{l}47.3 \pm \\
5.6^{\mathrm{e}}\end{array}$ & $1.03 \pm 0.09^{\mathrm{e}}$ \\
\hline $\begin{array}{l}\text { Fish oil feed level } \\
10 \% \\
\text { cholesterol }\end{array}$ & $\begin{array}{l}121.29 \quad \pm \\
6.9^{d}\end{array}$ & $100.4 \pm 2.4^{b}$ & $\begin{array}{l}33.82 \\
\pm 3.5^{d}\end{array}$ & $\begin{array}{l}68.7 \pm \\
1.3^{b}\end{array}$ & $2.02 \pm 0.33^{b}$ \\
\hline $\begin{array}{l}\text { Fish oil feed level } \\
15 \% \\
\text { cholesterol }\end{array}$ & $\begin{array}{l}147.29 \\
3.53^{\mathrm{b}}\end{array}$ & $85.8 \pm 2.8^{\mathrm{c}}$ & $\begin{array}{l}40.71 \\
\pm 3.2^{c}\end{array}$ & $\begin{array}{l}53.3 \pm \\
4.7^{\mathrm{d}}\end{array}$ & $1.31 \pm 1.0^{\mathrm{d}}$ \\
\hline
\end{tabular}

Each value represent the mean of 5 rats \pm SD. Values significantly different compared to normal: $P \leq 0.05$. Same letter means non-significant.

2-2- Effect of pizza supplemented with different levels of fish oil on liver functions of hypercholesterolemic rats.

Results of aspartate amine transferase (AST) and alanine amine transferase (ALT) are presented in table (3) . 
Hypercholesterolemic rats (control +) showed significant increasing in both AST and ALT enzyme levels compared with the healthy rats (control -).

Results obtained from this table stated that a significant increasing $(\mathrm{P} \leq 0.05)$ in the mean values of ALT enzyme in the group fed on hypercholesterolemic diet $($ control +) compared with the other groups.

Data showed that serum ALT levels were decreased significantly $(\mathrm{P} \leq 0.05)$ in all tested groups that fed on different levels of fish oil in pizza compared with the control (+), especially the group of rats fed on basal diet containing $15 \%$ fish oil in pizza, feeding hypercholesterolemic rats on basal diet containing $15 \%$ fish oil in pizza showed non-significant changes in AST enzyme, when compared negative control.

Feeding hypercholesterolemic rats with basal diet containing $15 \%$ fish oil in pizza was the best mean value obtained, because these treatments led to highest reduction in AST and ALT enzymes, as compared to other groups. The obtained results were in parallel with Zhu et al.(2012) found that Posttransplant parenteral nutritional support combined with omega-3 fatty acids can significantly improve the liver in jury, reduce the infectious morbidities, and shorten the post-transplant hospital stay.

Table (3):Effect of pizza supplemented with different levels of fish oil on liver functions of hypercholesterolemic rats.

\begin{tabular}{|l||l||l|}
\hline Groups & AST & ALT \\
\hline \hline Control negative & $18.05 \pm 1.3^{\mathrm{e}}$ & $9.78 \pm 0.94^{\mathrm{c}}$ \\
\hline \hline Control positive & $37.21 \pm 2.3^{\mathrm{a}}$ & $16.01 \pm 1.1^{\mathrm{a}}$ \\
\hline Fish oil feed level 10\% & $29.31 \pm 0.39^{\mathrm{c}}$ & $14.44 \pm 0.45^{\mathrm{b}}$ \\
\hline Fish oil feed level 15\% & $22.4 \pm 5.3^{\mathrm{d}}$ & $10.3 \pm 0.91^{\mathrm{d}}$ \\
\hline $\begin{array}{l}\text { Fish oil feed level 10\% } \\
\text { with cholesterol }\end{array}$ & $33.67 \pm 0.9^{\mathrm{b}}$ & $15.29 \pm 0.3^{\mathrm{a}}$ \\
\hline $\begin{array}{l}\text { Fish oil feed level } \\
\mathbf{1 5 \%} \text { with cholesterol }\end{array}$ & $29.1 \pm 2.3^{\mathrm{c}}$ & $12.43 \pm 1.21^{\mathrm{c}}$ \\
\hline
\end{tabular}

Each value represent the mean of 5 rats \pm SD. Values significantly different compared to normal: $P \leq 0.05$. Same letter means non-significant.

\section{2-3-Effect of pizza supplemented with different levels of fish oil on kidney} functions of hypercholesterolemic rats:

The effect of fish oil on serum uric acid and urea nitrogen of hypercholesterolemic rats fed on basal diet containing pizza with 10 and $15 \%$ fish oil and hypercholesterolemic rats fed on hypercholesterolemic diet containing pizza with 10 and $15 \%$ fish oil are presented in table (4).

The mean values of serum uric acid and urea nitrogen $(\mathrm{mg} / \mathrm{dl})$ for experimental group that fed on basal diet only were $0.75 \pm 0.32$ and $14.7 \pm 0.08$, respectively, while uric acid and urea nitrogen of hypercholesterolemic rats 
(positive control) were $1.78 \pm 0.31$ and $26.6 \pm 2.3$, respectively. Results revealed that, rats with hypercholesterolemic diet (control +) led to a significant increase $(\mathrm{P}<0.05)$ in serum uric acid and urea nitrogen, when compared with (control - ). The lowest mean values of serum uric acid of tested groups was observed in the group of hypercholesterolemic rats fed on basal diet containing $15 \%$ fish oil in pizza, while the highest mean values was occurred when hypercholesterolemic rats fed on hypercholesterolemic diet containing $10 \%$ fish oil in pizza.

On the other hand, feeding hypercholesterolemic rats on hypercholesterolemic diet containing 10 and $15 \%$ fish oil in pizza showed significant increased $(\mathrm{P} \leq 0.05)$ in urea nitrogen as compared to hypercholesterolemic rats fed on basal diet containing pizza with 10 and $15 \%$ fish oil.

Hypercholesterolemic rats (control +) showed significant increasing in both creatinine and albumin levels compared with the healthy rats (control -).

Data showed that serum creatinine and albumin levels were decreased significantly $(\mathrm{P} \leq 0.05)$ in all tested groups that fed on different levels of fish oil compared with the control $(+)$.

On other hand, hypercholesterolemic group that fed on basal diet containing $15 \%$ fish oil in pizza as treatment showed decreasing in creatinine levels compared to control (-), hypercholesterolemic groups that fed on basal diet containing 10 and $15 \%$ fish oil in pizza as treatment and hypercholesterolemic group that fed on hypercholesterolemic diet containing $15 \%$ fish oil in pizza showed decreasing in albumin levels compared to control (-). These results matched with Rossing $\boldsymbol{e t}$ al. (1996) who suggested that dietary supplementation with n-3 polyunsaturated fatty acids (fish oil) may have beneficial effects on kidney function as albumin and urea, arterial blood pressure, and dyslipidemia.

Table (4): Effect of pizza supplemented with different levels of fish oil on kidney functions of hypercholesterolemic rats.

\begin{tabular}{|c|c|c|c|c|}
\hline Groups & Uric acid & Urea Nitrogen & Creatinine & Albumin \\
\hline Negative Control & $0.75 \pm 0.32^{d}$ & $14.7 \pm 0.08^{\mathrm{e}}$ & $0.83 \pm 0.12^{\mathrm{b}}$ & $3.90 \pm 1.23^{\mathrm{a}}$ \\
\hline Positive Control & $1.78 \pm 0.31^{\mathrm{a}}$ & $26.6 \pm 2.3^{\mathrm{a}}$ & $0.97 \pm 0.03^{\mathrm{a}}$ & $3.97 \pm 0.87^{\mathrm{a}}$ \\
\hline Fish oil feed level $10 \%$ & $1.54 \pm 0.25^{b}$ & $21.9 \pm 0.6^{\mathrm{c}}$ & $0.8 \pm 0.11 \mathrm{c}$ & $3.6 \pm 0.94^{\mathrm{a}}$ \\
\hline Fish oil feed level $15 \%$ & $1.23 \pm 0.11^{\mathrm{c}}$ & $18.4 \pm 2.2^{\mathrm{d}}$ & $0.76 \pm 0.31 \mathrm{c}$ & $3 \pm 0.44^{\mathrm{a}}$ \\
\hline $\begin{array}{l}\text { Fish oil feed level } 10 \% \text { with } \\
\text { cholesterol }\end{array}$ & $1.71 \pm 0.41^{\mathrm{a}}$ & $24.6 \pm 1.4^{b}$ & $0.9 \pm 0.22^{\mathrm{a}}$ & $3.9 \pm 0.32^{\mathrm{a}}$ \\
\hline $\begin{array}{l}\text { Fish oil feed level } 15 \% \text { with } \\
\text { cholesterol }\end{array}$ & $1.51 \pm 0.06^{b}$ & $22.7 \pm 2.7^{c}$ & $0.87 \pm 0.25^{\mathrm{b}}$ & $3.6 \pm 0.51^{\mathrm{a}}$ \\
\hline
\end{tabular}

Each value represent the mean of 5 rats \pm SD. Values significantly different compared to normal: $P \leq 0.05$. Same letter means non-significant. 
2-4-Effect of pizza supplemented with different levels of fish oil on Hormones femininity:

The effect of feeding different levels from fish oil in pizza on hormones femininity (Progesterone and PRL) of hypercholesterolemic rats, are presented in table (5). The mean value of Progesterone hormone for negative control was $8.85 \pm 1.23$, while it was $4.177 \pm 0.98$ for hypercholesterolemic group as positive control. Results in this table showed decreasing in Progesterone hormone of control (+) as compared to control (-). All groups under test as treatment showed increasing in Progesterone hormone values compared to control (-).

Hypercholesterolemic groups that fed on basal diet containing $10 \%$ and $15 \%$ fish oil in pizza as treatment showed decreasing in progesterone hormone values compared to the groups fed on hypercholesterolemic diet containing $10 \%$ and $15 \%$ fish oil in pizza as prevention. PRL hormone of the group fed on hypercholesterolemic diet (control + ) showed increase as compared to negative group (control -). Hypercholesterolemic groups that fed on basal diet containing $10 \%$ and $15 \%$ fish oil in pizza as treatment showed decreasing in PRL hormone values compared to the groups fed on hypercholesterolemic diet containing $10 \%$ and $15 \%$ fish oil in pizza as prevention.

Hypercholesterolemic group that fed on basal diet containing 15\% fish oil in pizza as treatment showed decreasing in PRL hormone values compared to the group fed on basal diet containing $10 \%$ fish oil in pizza. In the same line Staziaki, et al. (2013) who stated the positive effect of chronic fish oil (FO) supplementation (rich in omega-3 polyunsaturated fatty acids) on femininity hormones behavior as progesterone and oxidative stress of Wistar female rats

Table (5): Effect of pizza supplemented with different levels of fish oil on Hormones femininity.

\begin{tabular}{|l||l|l|}
\hline Groups & Progesterone & PRL \\
\hline \hline Negative Control & $8.85 \pm 1.23^{\mathrm{a}}$ & $0.023 \pm 0.002^{\mathrm{d}}$ \\
\hline \hline Positive Control & $4.177 \pm 0.98^{\mathrm{d}}$ & $0.097 \pm 0.01^{\mathrm{a}}$ \\
\hline \hline Fish oil feed level 10\% & $6.57 \pm 0.78^{\mathrm{b}}$ & $0.037 \pm 0.002^{\mathrm{c}}$ \\
\hline \hline Fish oil feed level 15\% & $7.24 \pm 0.6^{\mathrm{b}}$ & $0.023 \pm 0.001^{\mathrm{d}}$ \\
\hline \hline Fish oil feed level 10\% with cholesterol & $4.66 \pm 0.57^{\mathrm{d}}$ & $0.067 \pm 0.001^{\mathrm{b}}$ \\
\hline \hline Fish oil feed level 15\% with cholesterol & $5.493 \pm 0.72^{\mathrm{c}}$ & $0.055 \pm 0.002^{\mathrm{c}}$ \\
\hline \hline
\end{tabular}

Each value represent the mean of 5 rats \pm SD. Values significantly different compared to normal: $P \leq 0.05$. Same letter means non-significant.

\section{Conclusions:}

The study clearly demonstrates that Using fish oil and cod liver oil as supplementation in the therapeutic diet menus during medical care of hyperlipidemic patients to maintain good health and improve of lipid profile, kidney function, liver functions and Hormones femininity levels in blood. 


\section{References:}

Awad, V.S.O.(1998): Nutritional Care for Patients with Diabetes Mellitus in Chabiya Governorate. PH.D. Thesis, Faculty of Home Economics, Minufiya University, Egypt.

Barham, D and Trinder, P.(1972): Determination of uric acid. Analyst, 97:142.

Biggerstaff, K. D. and Wooten, J. S.(2004): Understanding lipoproteins as transporters of cholesterol and other lipids. Adv. Physiol. Educ., 28 (3): 105-106.

Burillo, E.; Martin-Fuentes, P.; Mateo-Gallego, R.; Baila-Rueda, L.; Cenarro, A.; Ros, E. and Civeira, F.(2012): Omega-3 fatty acids and HDL. How do they work in the prevention of cardiovascular disease?.Current Vascular Pharmacology. 10(4):432-41.

Carmena, R.; Duriez, P. and Fruchart, J.(2004): Atherogenic Lipoprotein Particles in Atherosclerosis. Circulation, 109: III-2-III-7.

Carrepeiro, M.M.; Rogero, M.M.; Bertolami, M.C.; Botelho, P.B.; Castro, N. and Castro, I.A.(2011): Effect of $n-3$ fatty acids and statins on oxidative stress in statin-treated hypercholestorelemic and normocholesterolemic women. Atherosclerosis. 217(1):171-8.

Champman, D.G.; Castilla, R. and Cambell, J. A. (1959): Evaluation of protein in food. I.A method for the determination of protein efficiency ratio. Can. J. Biochem. Physiol., 37 : 679- 686.

Chen, J.; Jiang, Y.; Liang, Y.; Tian, X.; Peng, C.; Ma, K.Y.; Liu, J.; Huang, Y. and Chen, Z.Y.(2012): DPA n-3, DPA n-6 and DHA improve lipoprotein profiles and aortic function in hamsters fed a high cholesterol diet. Atherosclerosis. 221 (2):397-404.

Dhuley, J.; Naik, S. R. and Rele, S. (1999): Pharm. Pharmacol. Commun., 5:689.

Doumas, B. T. and Biggs, H. G.(1971): Albumin standard and measurement of serum albumin with bromocresol green. J. Clin. Chem., 5(8):31:79.

Durrington, P. (2003): Dyslipidaemia" lancet 362 (9358):717-31. Doi 21010-1016/50140-6736 (03) 14234-10 PMID 197096.

Herzberg, G.R.(1991): Dietary regulation of fatty acid triglyceride metabolism. Con. J. Physiolpharmacoll., 69: 1637-1647.

Hirai, H. (1982) : Alpha fetoprotein. In: Chu TM. (ed.) Biochemical Markers for Cancer. Marcel Dekker, New York .23-59.

Hirako, S.; Kim, H.J.; Shimizu, S.; Chiba, H. and Matsumoto, A.(2011): Low-dose fish oil consumption prevents hepatic lipid accumulation in high cholesterol diet fed mice. Journal of Agricultural \& Food Chemistry. 59(24): 13353-9.

Farish, E. and Fletcher, C.O.(1983): A comparison in two micro- methods for determination of HDL2 and HDL3 cholesterol. Clin. Chim. Acta., 129 : 221-228. 
Fawcett, J. K. and Scott, J. E.(1960):Anaccurate and rapid method for determination of proteins in small amounts of blood serum and plasma. Am. J. Clin. Path., 16-40.

Kontush, A. and Chapman, M. J.(2006): Antiatherogenic small, dense HDLguardian angel of the arterial wall. Nature Clinical Practice Cardiovascular Medicine, 3: 144-153.

Leaf, A. and Weler, P.C.(1988): Cardiovascular effects of n-3 fatty acids. NEng. J Med; 318: 318-557.

Lee, S.P.; Dart, A.M.; Walker, K.Z.; O'Dea, K.; Chin-Dusting, J.P. and Skilton, M.R.(2012): Effect of altering dietary n-6:n-3 PUFA ratio on cardiovascular risk measures in patients treated with statins: a pilot study. British Journal of Nutrition. 108(7): 1280-5.

Liu, M.; Wallin, R. and Saldeen, T.(2001): Effect of bread containing stable fish oil on plasma phospholipids' fatty acids. triglycerides. HDLcholesterol. and malondialdehyde in subjects with hyperlipidemia. Nutrition Research, 21 (11): 1403-1410.

Reitman, A. and Frankel, S.(1957): GPT and GOT determination after enzymatic hydrolysis. Amer. J. Clin. Path., 28-56.

Rossing, P.; Hansen, B.V.; Nielsen, F.S.; Myrup. B.; Holmer, G. and Parving, H.H.(1996): Fish oil in diabetic nephropathy. Diabetes Care. 19(11): 1214-9, 1996 Nov.

Ruzickova, J.; Rossmeisl, M.; Prazak, T.; Flachs, P.; Sponarova, J.; Veck, M.; Tvrzicka, E.; Bryhn, M. and Kopecky, J.(2004): Omega-3 PUFA of marine origin limit diet-induced obesity in mice by reducing cellularity of adipose tissue. Lipids. 2004 Dec;39(12):1177-85.

Schimeister, J.(1970): HDL cholesterol and risk ratio Determination after separation high-density lipoprotein. Lipid. Res., 11:583. Capsicum in rat Res. Commun. Chem. Pathol. Pharmced., 41(1):95-110.

Staziaki, P.V.; Marques, C.M.; Delattre, A.M.; de Paula Cioni, B.; Rufino, M.; Dos Santos, F.V.; Licks, F.; Marroni, N.P. and Ferraz, A.C.(2013): Fish oil has beneficial effects on behavior impairment and oxidative stress in rats subjected to a hepatic encephalopathy model. CNS NeurolDisord Drug Targets. 2013 Feb 1;12(1):84-93.

Vas. Handel, V.E. and Zilversmit, D.B.(1957): Micro method for the direct determination of serum triglycerides. J.Lab. Clin. Med., 50:152.

Wotton, I.D.P.(1964): Microanalysis in medical biochemistry. $4^{\text {th }}$ edition Ed. By. J. and A. Churchill Ltd., Gioucester Loce, W.I., London.

Zhu, X.H.; Wu, Y.F.; Oiu, Y.D.; liang, C.P. and Ding, Y.T.(2012): Liverprotecting effects of omega-3 fish oil lipid emulsion in liver transplantation.World J Gastroenterol. 2012 Nov 14:18(42):6141-7 doi: 10.3748/wjg.vl8.i42.6141. 